\title{
Sea-Land Limits: a case study
}

\author{
AFRANiO R. DE MESQUiTA ${ }^{1}$, DENIZAR BLITZKOW ${ }^{2}$, CARLOS A.S. FRANÇA ${ }^{1}$, \\ JORGE L.A. TRABANCO ${ }^{3}$, MARCO A. CORRÊA ${ }^{1}$ and MAURO Q. MONTEIRO ${ }^{1}$ \\ ${ }^{1}$ Instituto Oceanográfico da USP, Cidade Universitária, 05508-900 São Paulo, SP, Brasil \\ ${ }^{2}$ Escola Politécnica da USP, Cidade Universitária, 05508-900 São Paulo, SP, Brasil \\ ${ }^{3}$ Faculdade de Engenharia Civil, UNICAMP, Departamento de Engenharia Civil, 13083-852 Campinas, SP, Brasil
}

Manuscript received on November 12, 2010; accepted for publication on March 28, 2011

\begin{abstract}
The limits between sea and land were estimated at "Pulso" beach located in the Southeastern Brazilian shelf $\left(\phi=23^{\circ} 33^{\prime} 17.4886^{\prime \prime} \mathrm{S} ; \lambda=045^{\circ} 13^{\prime} 13.0504^{\prime \prime} \mathrm{W}-\mathrm{WGS} 84\right)$, between the island of São Sebastião and the city of Ubatuba, SP, Brazil. The relative sea level of the year 1831 at "Pulso" beach, as per Brazilian law Number 9760 dated from 1946, was estimated and materialized. The retro-estimation allowed the demarcation of the Legal Sea-Land Limits at "Pulso" beach as per the terms of the law. The accuracy of the procedure for the transference of the longterm sea level from the research station of Ubatuba to "Pulso" beach was assessed by parallel work of geometrical leveling referred to the IBGE (Brazilian Institute of Geography and Statistics) geodetic network. The motivation, the hypotheses (Brest, Cananeia and IPCC) and the methods here used are described, together with a short history of the Legal Sea-Land Limits. The results indicated that the legal Sea-Land Limits at "Pulso" beach are well within the beach area. They were determined as per law 9760, and there is the need to reactivate the national network of sea level gauge.
\end{abstract}

Key words: Relative Sea Level, Brazilian law, Sea-Land Limits, "Pulso" beach, geodetic leveling, Southeastern Brazilian shelf, global warming, sea level rise.

\section{INTRODUCTION}

This work is a follow-up of previous results obtained at "Barra do Una" beach by Mesquita et al. (in press) in the Southeastern Brazilian Shelf (Fig. 1), and goes along with the difficulties concerning the federal regulation as provisioned in law 9.760 of 1946 for the legal determination of the land property along the shores. There is the need to comply, "ipsis litteris", with the legal terms. So, one need to know where is the relative sea level of the year 1831 at "Pulso" beach.

Solving this problem is very difficult because, although the sea level records of 1831 obtained in Rio de Janeiro Harbor are well kept in the Museum of the Directory of Hydrography and Navigation of the

Correspondence to: Afranio R. de Mesquita

E-mail: ardmesqu@usp.br
Brazilian Navy, there has not been any information so far about the geographical positioning of the "datum" relative to which the sea level of 1831 was referred to. Due to this reason, the mean sea level of 1831 of Rio de Janeiro, mentioned in the 1946 law as the National reference for the purpose of legally fixing the land limits with respect to the oceans, cannot be materialized in Rio de Janeiro Harbor and the application, "ipsis litteris", of the law to any part of the coast is not possible.

Aiming at assessing the method already used in the solution of the problem by Mesquita et al. (in press) for the "Una" beach, a short account on the Legal Sea-Land Limits is given, and also a description of the work performed at "Pulso" beach. The methods used to obtain the relative sea level of "Pulso" beach are also described with the determination by retro-estimation of the Mean of High Waters (MHW) of 1831. 


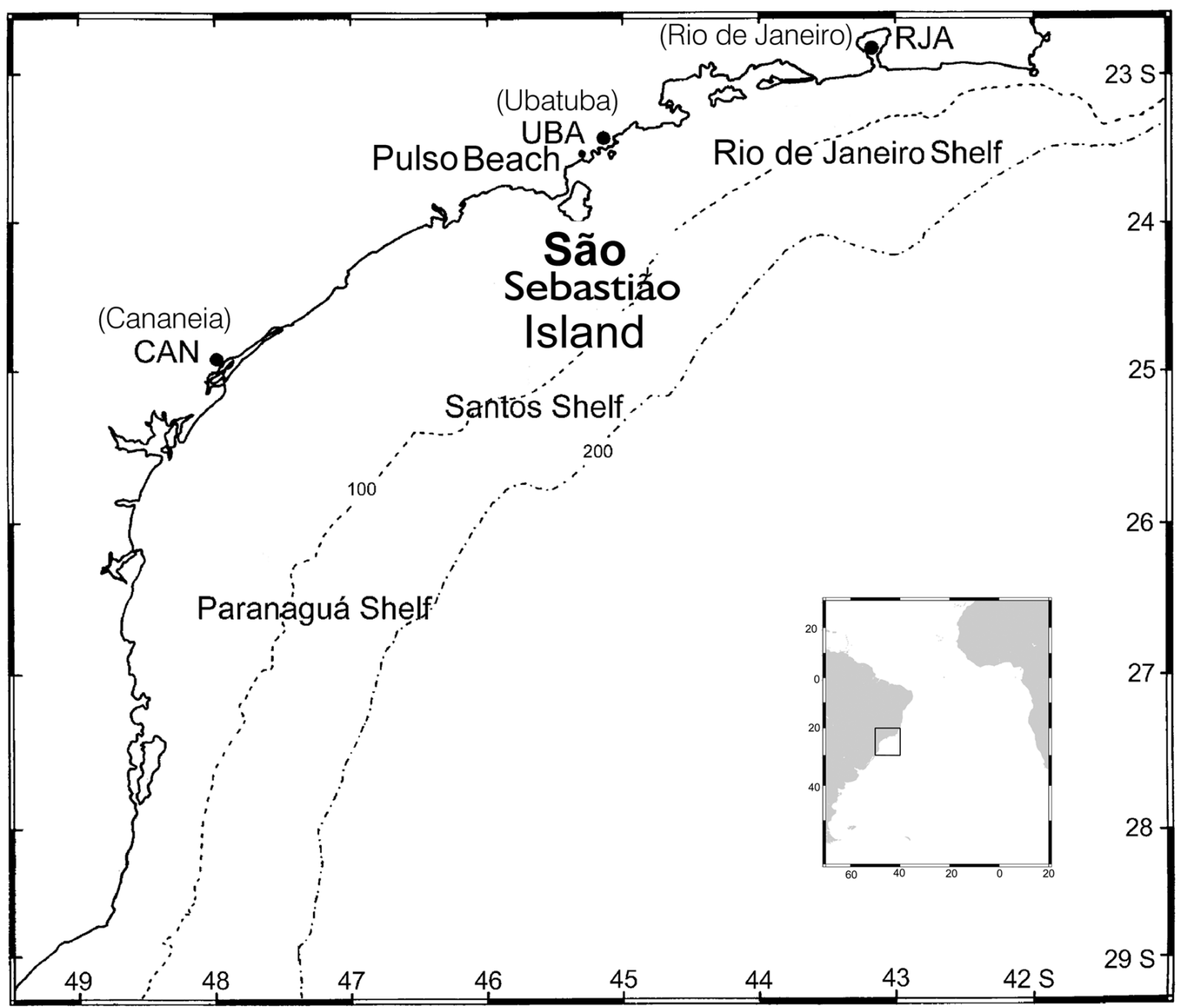

Fig. 1 - View of the South Eastern Brazilian Shelf showing the positioning of the Island of São Sebastião and the city of Ubatuba, between which, the measurements at "Praia do Pulso" (PP), have been taken.

The results indicate that the methods are adequate to solve the Sea-Land Limits problem, leading to a discussion on the current global warming in the sea level variation.

\section{LEGAL SEA-LAND LIMITS}

Legal Sea-Land Limits is the area along the beach that is swept by a line $33 \mathrm{~m}$ long from the MHW of the year 1831 towards the land. The first news, which led to the definition of these limits concerning the regulations for constructions along the beaches, date from October $21^{\text {st }}$, 1710 , and were published in the "Ordem Régia" from the Portuguese Crown, which asked the Governor of Rio de Janeiro to inform about the houses that were built along the town beaches. Other past and present governmental regulatory measures regarding the federal taxation for constructions that invade the legal limits of the beach can be found in "Serviço do Patrimônio da União" (SPU) (1999).

The first measurements of the sea level in the Land of Santa Cruz, Brazil's second given name (the first name was Ilha de Vera Cruz), were taken at Guanabara Bay, Rio de Janeiro, near the open bar to the Atlantic during 1731 and 1732 , by the Portuguese astronomer Sanches Dorta (Belfort Vieira 1928).

By the beginning of the $20^{\text {th }}$ century, there were the first local contributions to the knowledge of the sea level science based on the sea level data gathered by the 
"Inspetoria Federal de Portos, Rios e Canais" (IFPRC) as shown in Lemos (1928), and in the Directory of Hydrography and Navigation (DHN) (Tábuas 1989). These contributions continued after the University of São Paulo (USP) foundation in 1934, which settled in the 50's and 60 's and still operates, through its Institute of Oceanography (IO-USP), permanent stations for measuring the relative sea level in the cities of Cananeia and Ubatuba (Fig. 1).

Not much later, the law 9.760 dated from 1946, Section II, article 2, which deals with the issues of properties of the Brazilian federation of states, determined that the legal limits have to be measured regarding the mean sea level of 1831 or, more precisely, the MHW of 1831. The sea level records of 1831 for the calculation of the mean sea level are presently at the Museum of the Directory of Hydrography and Navigation of the Brazilian Navy. However, so far, there has not been any information about the location of the "datum" to which the 1831 records were referred to in Rio de Janeiro Harbor. This is the scenario that this Sea-Land Limits case study deals with.

\section{MATERIALS AND METHODS}

"Pulso" beach is along the coast of the state of São Paulo in the Southeastern Brazilian coast, as shown in Figure 1. This beach is nearby "Caçandoca" beach, where the first oceanographic interdisciplinary research program was carried out by the IO-USP for the Geophysical year of United Nations Educational, Scientific and Cultural Organization (UNESCO) in 1958.

The coordinates of "Pulso" beach were determined with the Global Positioning System (GPS), Trimble system, model 4000 SSI, with double frequency. The GPSURVEY software was used, which allows the processing of stations by the static method. The coordinates were referred to the Brazilian Network for Continuous GPS Monitoring (RBMC) through the stations of Presidente Prudente, SP, and Curitiba, PR. They were materialized via marks in concrete and bronze metal plates on the ground (Pulso 1) and fixed on the rocks (Pulso 2). Table I shows their positions and orthometric heights.

The measurements of relative sea level taken with a stilling well buoy AOTT gauge at the Research Base "Clarimundo de Jesus" of the IO-USP in Ubatuba were performed for the long-term sea level calculations. The gauge has produced sea level data for nearly 40 years in an almost continuous data set. The equipment and its first and original datum are described in Mesquita and Harari (1983).

Spirit leveling was referred to the mean sea level of the Imbituba Harbor, which was adopted by the Brazilian Institute of Geography and Statistics (IBGE) as the national datum for the leveling work over the country, replacing the Reference Level (RN), or Bench Marks (BM) of Rio de Janeiro Harbor whose location is, so far, unknown. Figure 2 shows the distribution of the main points chosen for the leveling work at "Pulso" beach, and Figure 3 shows the main points for RN, or BM, in the Ubatuba research station.

The leveling of the BM, (RN2), was first fixed at "Cassandoquinha" beach in a field work (Miniussi 1963, Occhipinti 1963) for the first interdisciplinary campaign of the IO-USP during the International Geophysical Year in 1958. The work was then repeated, by the spirit leveling of "Pulso" beach, which was extended to "Cassandoquinha" beach.

The results of the leveling network are summarized in Figure 3 for the Ubatuba sea level gauge, showing the measurements, expressed in meters, related to the IBGE's BM 1979X, and the mean sea level values of the field work period (30/05-03/06/03), when simultaneous measurements of sea level heights were taken in "Pulso" beach and Ubatuba.

In Figure 2, the vertical distances of the BM of Pulso 1 and Pulso 2 were measured concerning the IBGE's BM 1980F. The leveling activities of Miniussi (1963) in 1958 were accessed by this study, which allows to refer its height (RN2) to the mean sea level of the research station of Ubatuba, as shown in Table I.

\section{RESULTS}

Measurements at "Pulso" beach were taken at every 15minute interval by visual reading of the tidal staff with readings up to the centimeters for 5 days, 12 hours per day, from 6 am to $6 \mathrm{pm}$. The recorded mean values of the sea level sites were $0.94 \mathrm{~m}$ and $1.51 \mathrm{~m}$ for this beach and Ubatuba, respectively, with a difference for their zero values to the mean sea level period (30/05-03/06/ 03) of $0.57 \mathrm{~m}$. 


\section{TABLE I}

Results of GPS positioning of the Pulso beach on planet Earth. Positioning is given in Universal Topographic Units (UTM) expressed in meters, which have reference in the meridian of $45^{\circ} \mathrm{W}$ and latitude 0 degrees. - UTM System of Coordinates - Meters - Relative to SAD 69 (Caçandoca, Cassadoquinha and other indicate the same beach).

\begin{tabular}{c|c|c|c}
\hline Station & East & North & $\begin{array}{c}\text { Orthometric } \\
\text { altitude }\end{array}$ \\
\hline Pulso 1 & 477561.6563 & 7395084.16398 & 1.4240 \\
\hline Pulso 2 & 478114.0284 & 7394941.54819 & \\
\hline Cassandoca & 477347.1835 & 7395640.917 & 2.202 \\
\hline
\end{tabular}

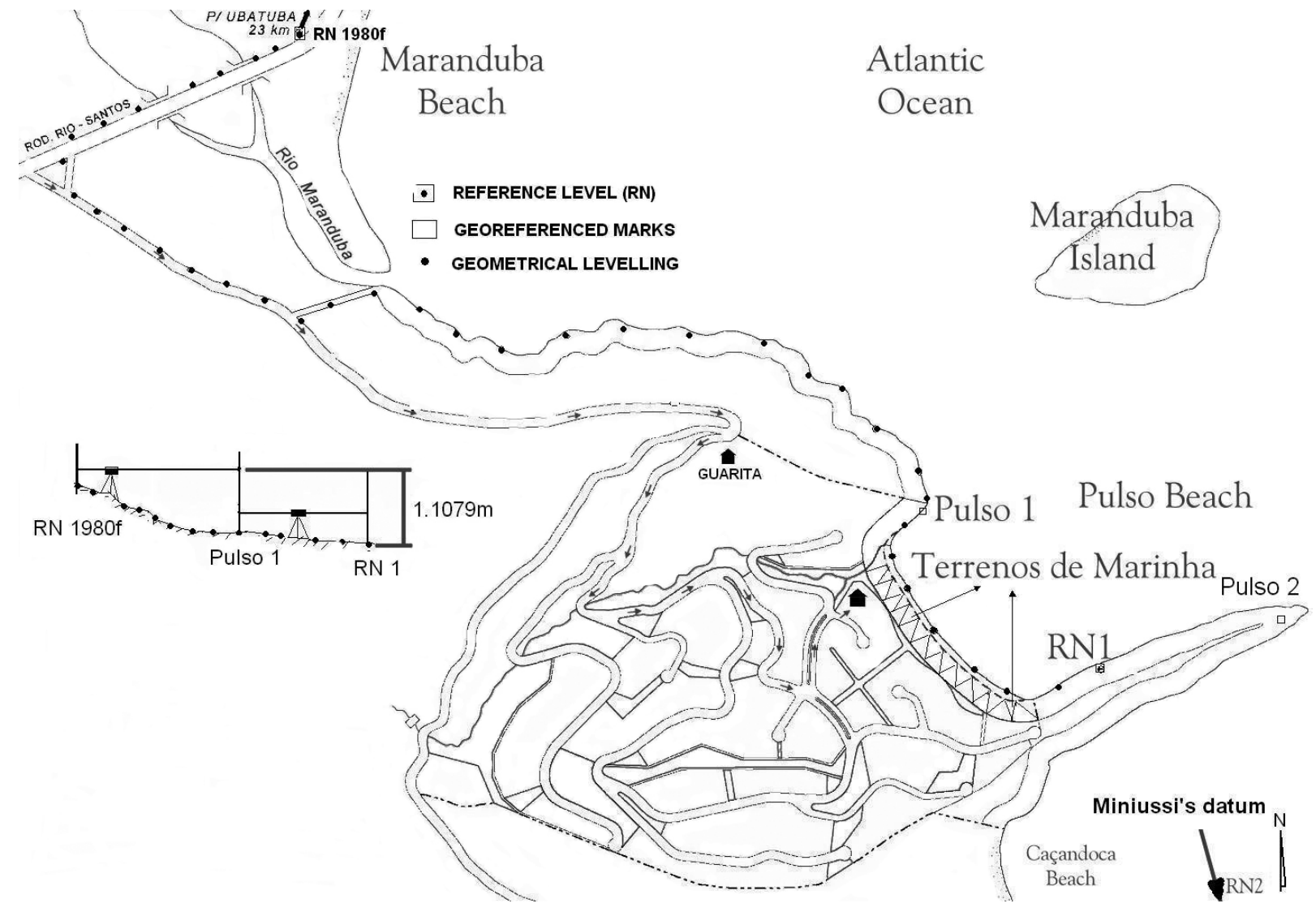

\section{Atlantic \\ Ocean}

Fig. 2 - Leveling at Praia do Pulso (PP), with the indications of locations where the reference level was fixed for geo-referencing and positioning for sea level measurements - (PULSO1- PULSO2-, RN1) and the indication of the Caçandoca Beach, to where the leveling work was also extended to repeat previous leveling work made during the Geophysical Year of 1958 (RN2), by Miniussi (1963). 


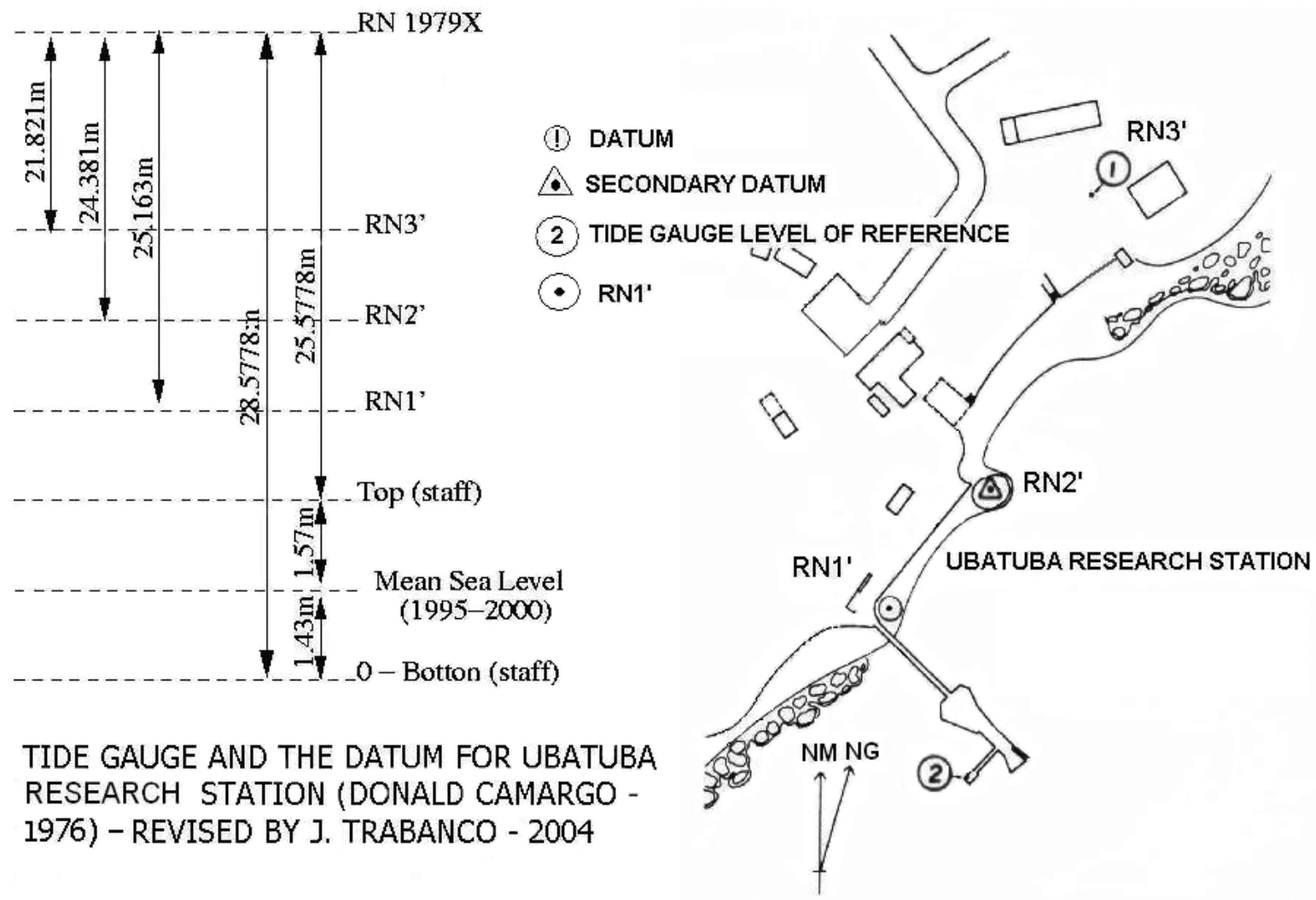

Fig. 3 - Mesquita and Harari (1983) leveling - revised by Eng. J.L.A. Trabanco (2004), after the rebuilding work made at the pier, where the AOTT tide measurement facilities are. Numbers on the left side of the Figure represent the vertical distances relative to IBGE's 1979X level of reference $(\mathrm{RN})$. The vertical distance of RN1' to the top of the tidal staff, in its new position, is $0.415 \mathrm{~m}$.

By assuming that the sea level of both places are physically the same (i.e. would not differ from the spirit leveling), and bearing in mind that they are relatively close places, the sea level of both places were adjusted and taken as the same one. The places have synchronous variation with slightly larger amplitude at "Pulso" beach than at Ubatuba. The rate of amplitudes "Pulso" beach/Ubatuba was estimated as 1.02 .

This rate was used to estimate the MHW at "Pulso" beach in 1831 from the knowledge of its corresponding MHW values in Ubatuba. This was obtained by retro-prediction, using the harmonic constants of Ubatuba given by Mesquita and Harari (1983) and applying the procedures provided by A.R. de Mesquita and C.A.S. França (unpublished data) for the retrocalculation. The effectiveness of this procedure was tested by making the prediction of the sea level of Ubatuba, which was actually recorded during the field work period, and by comparing their series of values.
The Ubatuba retro-predicted MHW in 1995-2000 was determined by using the tidal constants of Ubatuba as $0.334 \pm 0.005 \mathrm{~m}$. The current MHW was also obtained from the Ubatuba measurements for the same period, as $0.332 \pm 0.007 \mathrm{~m}$. The values of the current and retro-predicted values are very much the same, showing that the retro-prediction can be used for the estimation of the MHW of "Pulso" beach in 1831, and one of the above values is used in the present calculations to get the current estimated value of the MHW of "Pulso" beach in this year.

To estimate the corresponding 1995-2000 longterm Mean Sea Level value (MSL) for "Pulso" beach, it is necessary first to subtract $0.57 \mathrm{~m}$. The difference of the zeros of the tide staffs, from the corresponding MSL of the same period of Ubatuba, gave $0.86 \mathrm{~m}$.

In order to estimate the MHW of "Pulso" beach, it is necessary to add the MSL value $(0.86 \mathrm{~m})$ to the MHW one $(0.332 \mathrm{~m})$ multiplied by the rate of heights 
of both places, which gives $0.338 \mathrm{~m}$. The result of the addition $0.86+0.338$ is $1.198 \mathrm{~m}$, which is the current value (year 2000) of the MHW of "Pulso" beach relative to the zero of the tidal staff of this beach.

To estimate the long-term value of the MSL of 1831 at "Pulso" beach, it is necessary, first of all, to estimate how far the current MSL of $0.86 \mathrm{~m}$ is from the position it was in 1831, when the sea level was lower down in the beach.

It is well known that the global sea level has risen since 1831 in tropical and subtropical areas that include the Southeastern coast of Brazil. So, in order to produce this estimate, i.e. how far is the current MSL of "Pulso" beach from its position of 1831, three hypotheses were considered:

1) That the sea level of "Pulso" beach has varied, from 1831 until now at the same rate of the Brest Harbor in France, which is one of the few harbors of the world that has recorded the sea level since 1807 (PSMSL 1999), and included the year 1831 as provisioned in law 9760. The long-term relative MSL of Brest of 2000 and its rate of sea level variation were calculated from the current series of mean annual data of Brest.

http://www.pol.ac.uk/psmsl/programmes/gloss/info.html.

From this series, the rate of increase of MSL in Brest is $9.6 \mathrm{~cm} / 100$ years, which gives for the period of 1831-2000 an increase of sea level of 169 years $\times 9.6 \mathrm{~cm} / 100$ years $=1.69 \times 9.6=16.22 \mathrm{~cm}$. In order to find out where in the beach is the MHW level of 1831 , the value $(16.22 \mathrm{~cm})$ must be diminished from the MHW value $(1.198 \mathrm{~m})$ of "Pulso" beach, giving $1.0358 \mathrm{~m}$ relative to the zero of the tidal staff of this beach.

2) That the MSL of "Pulso" beach has varied from 1831 until now at the same rate of the Cananeia Harbor in the state of São Paulo, where the relative sea level has been recorded since 1954. The longterm sea level of Cananeia in 2000 was estimated from the series of mean annual data as shown in França (2000). The rate of the sea level increase is nearly $40 \mathrm{~cm} / 100$ years, which gives for the period of 1831-2000 an increase of sea level of 169 years $\times 40 \mathrm{~cm} / 100$ years $=1.69 \times 40=67.6 \mathrm{~cm}$. If one wants to know where, in the beach, was the MHW of 1831 , the value $(67.6 \mathrm{~cm})$ must be diminished from the current value of $1.198 \mathrm{~m}$ of the MHW of "Pulso" beach, giving $0.522 \mathrm{~m}$.

3) That the sea level of "Pulso" beach has varied from 1831 until now at the same rate as the global estimate of Intergovernmental Panel for Climate Change (IPCC). The current global rate of relative sea level increase is $18 \mathrm{~cm} / 100$ years (Douglas 1991, Douglas et al. 1991), which gives for the period of 1831-2000 an increase of MSL of 169 years $\times 18 \mathrm{~cm} / 100$ years $=1.69 \times 18=$ $30.42 \mathrm{~cm}$. If one wants to know where, in this beach, is the MHW of 1831 , the value $(30.42 \mathrm{~cm}$ ) must be diminished from its current MHW value, giving $0.893 \mathrm{~m}$.

The values correspond to vertical distances of the levels of MHW concerning the zero of the tidal staff of "Pulso" beach. The vertical distances plotted in a graph as in Figure 4 show the distribution of all the MHW lines along the beach. As can be seen in the Figure, the distance between the 2000 year line and the MHW line of 1831 at this beach estimated by the Cananeia hypothesis is nearly $10 \mathrm{~m}$.

From this sort of scaling, one can also see in Figure 4 that the distance on the ground from the top most line, which is the MHW value of "Pulso" beach in 2000, to the demarcation line of private properties is greater than $33 \mathrm{~m}$.

This distance is greater than the Sea-Land Limits established by the law. It shows that the Legal Sea-Land Limits are entirely comprised within the beach and do not invade the area of private properties, no matter which hypothesis is chosen to apply the law.

\section{DISCUSSION}

There are different inclination rates of the relative sea level variation:

1) The rate of the relative sea level of tropical areas, which increase (positive rate) due to the heating of the oceanic layers (steric effect), together with the increase in the same direction due to a greater amount of fresh water, which is the result of the 
polar ice melting (eustatic effect), and the increase in volume of less saline (halosteric effect), which also gives a positive contribution to the rate of variation of the relative sea level.

2) The rate of the recorded relative sea level of polar areas due to post glacial alleviation of the crust (crustal effect) is negatively trended (negative rate) and, because of the readjustment of the mantle material, the recorded relative sea level in the tropical areas is positively trended, as examined in Peltier (2001).

3) The present rate of long-term glaciation of the Milankovitch period pointed out by Chao (1999), which seems to be negative and would favor a global decrease of the relative sea level.

Bearing in mind the above indications, it seems that only the measurements of the absolute sea level in the tropics and polar areas can access how the global adjustment of the sea level is occurring. For this, at the research stations of Ubatuba and Cananeia in the tropical South Atlantic, accurate measurements are being taken via GPS of the vertical motions of the crust. Measurements are taken in both stations of the relative and absolute gravity values (Blitzkow 1998, Franco 2000). Moreover, the relative sea level long-term AOTT data,have been gathered since 1967 in the research station of Ubatuba, and since 1947 in the research station of Cananeia.

Despite all the above directions of the rate of variation that seem to oppose each other, it is much likely in current days that the relative sea level, not only at Cananeia, but all over the Brazilian coast, may be rising at $40 \mathrm{~cm} / \mathrm{cty}$ (Mesquita et al. 1996). This is enough for the establishment of fair procedures that would allow the application of the 1946 law for the definition of the Sea-Land Limits based on the sea level of 1831, whatever may be the final result of the adjustment of the global MSL.

The legislator of 1946, when taking the relative sea level of 1831 as a geodetic reference for the application of the law, did not take into account the amount of knowledge produced by science during the period of 1831-1946. The new knowledge goes from the phenomenon of the glaciations to the phenomenon of current global warming, among others. These phenomena changed the location of the legal Sea-Land Limits of the beaches.

These limits, according to the 1946 law, are supposed to be immutable as if they were a permanent and solid beach property of the State, which is not true. This causes, in many cases, unlawful taxation of houses and buildings in the sea shore, which actually do not invade the Legal Sea-Land Limits. However, the owners of these properties are required to pay for this supposed invasion.

The procedure here described admits the mobility of the MSLfrom time to time by accepting the long-term rates of variation of the relative sea level via the hypotheses of Brest, Cananeia, and IPCC. The procedure takes into account influences that caused the sea level variation during the period of 1831-2003. This is used to estimate the current position of the MHW level of reference of 1831 as set by the 1946 law.

In order to make the procedure feasible and accurate, it was used a longer sea level series from a nearby permanent station in order to safely transfer its LongTerm Relative Sea Level (LTRSL) to "Pulso" beach. A longer series is more stable to get better values of the long-term mean sea level and of tidal constants. Better constants produce more accurate predictions and retrofletions. The AOTT long sea level series of the Ubatuba research station, with its nearly 40 years of measurements, was chosen for this purpose. This choice allowed the transference of the LTRSL of Ubatuba station to "Pulso" beach by assuming that the sea level for both places is the same. From the LTRSL of Ubatuba, the materialization of the MHW and the LTRSL of 1831 at this beach was obtained.

It was also necessary for the transference to certify that the seasonal, daily and diurnal variations of the sea level of the area (Franco and Mesquita 1986), (Fig. 1), were similar, so that the above hypotheses could be accepted and adopted for transferring these levels, as shown in Mesquita 1994, 1998, 2003. (See also www.mares.io.usp.br, icon "Praias Arenosas" Sandy Beaches).

Nowadays, the national reference for geodesic measurements (the national datum) is no longer the $1831 \mathrm{MSL}$, or LTRSL of Rio de Janeiro Harbor. For this purpose, the MSL of tide gauge data from Imbituba 


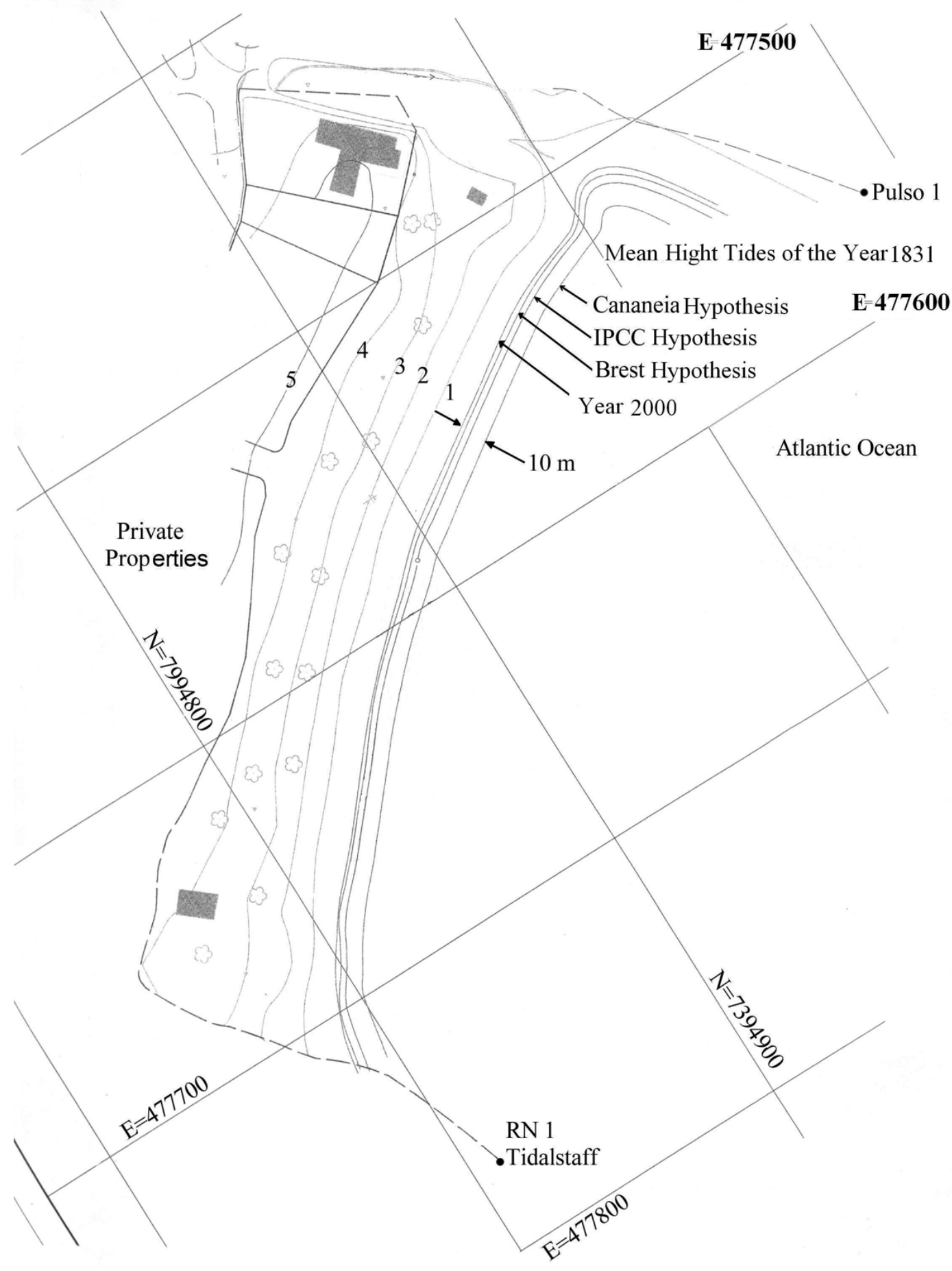

Fig. 4 - Mean Sea Level High Water (MHW) of "Praia do Pulso" (PP), of years 2000 and 1831, calculated according to the hypotheses: Brest, IPCC and Cananeia. The line of (MHW) of 2000 was obtained from the measurements at Ubatuba station, and the 1831 corresponding lines were drawn according to the hypotheses of Brest, Cananeia and IPCC. The horizontal distance among the external lines (Cananeia and Praia do Pulso 2000) of the set is nearly $10 \mathrm{~m}$. From this estimate, one sees that, by taking any of the lines for the mean level of (MHW) to start measuring $33 \mathrm{~m}$ horizontally towards the continent, from none of them the private properties are reached. The "Terrenos de Marinha" are totally along the beach. 
Harbor, in the Southern state of Santa Catarina, is now the reference adopted by the IBGE. It is not known how the mean sea level of Imbituba is related to the 1831 mean sea level of Rio de Janeiro stated by the 1946 law, but this lack of knowledge does not prevent the "ipsis litteris" application of the law if one can count on the current procedures to estimate the mean sea level position on the beaches all along the Brazilian coast in 1831.

Based on these procedures, Figure 4 clearly indicates that, for any of the previous hypotheses, the $33 \mathrm{~m}$ distance measured from the MHW of 1831 at "Pulso" beach towards the land is well within the sand area of the beach itself and, so, the beach is not invaded by the private properties, which, in this case, follow and obey the law of 1946.

Such sort of concern and accuracy in the legal demarcation of the sea $-33 \mathrm{~m}$ towards the land of the Legal Sea-Land Limits - may not be possible or obtainable in the beaches along the Brazilian coast due to a lack of a not too distant permanent sea level gauge and its series of data, which would be a series from a good long (19 years of continuous measurements) record for reference, in order to accept with certainty, the "same mean sea level" hypothesis for the transference of the sea level heights. This would allow the correct and lawful demarcation of the Sea-Land Limits in all beaches and harbors of the country. For this, the reactivation of the Brazilian sea level network of permanent stations that existed in the past may be required.

\section{CONCLUSION}

The measurement of the relative sea level at "Pulso" beach referred to the MHW of 1831, as established by Brazilian law number No 9.760 of 1946 through plausible hypotheses (Brest, Cananeia and IPCC) on the variation of global relative sea level from 1831 to the current days.

The accuracy of the procedures of sea level transference from Ubatuba station to "Pulso" beach based on the geographical proximity of the localities was assessed by precise parallel work of geometrical leveling and geo-referencing. Measurements of GPS positioning and orthometric heights were extended to the BM of "Caçandoca" beach, where the first IO-USP leveling work of the area was made in 1958 during the International Geophysical year. The results indicate that, for all the hypotheses raised in this case study, the $33 \mathrm{~m}$ limit of the Legal Sea-Land Limits at "Pulso" beach was entirely enclosed in the area of the beach, not invading the limits of private properties.

\section{ACKNOWLEDGMENTS}

We are grateful to Mr. Raimundo Antunes de Carvalho, Mr. Arildo Fernandes de Morais and Mrs. Maria Aparecida Simões, who have provided assistance with field work at "Pulso" beach and to the local Landlords, who have provided support regarding the expenses.

\section{RESUMO}

Os limites entre mar e terra foram estimados na praia chamada Pulso, localizada na costa sudeste do Brasil $(\phi=$ $\left.23^{\circ} 33^{\prime} 17,4886^{\prime \prime} \mathrm{S} ; \lambda=045^{\circ} 13^{\prime} 13,0504^{\prime \prime} \mathrm{W}\right)$ entre a Ilha de São Sebastião e a cidade de Ubatuba, no Estado de São Paulo, SP, Brasil. O nível relativo do mar do ano de 1831 na praia do Pulso, ou "Praia do Pulso" (PP), foi estimado e materializado, de acordo com a Lei brasileira Número 9760 de 1946. A acurácia do procedimento foi acompanhada por trabalho paralelo de nivelamento geométrico referido ao sistema nacional de geodésia do IBGE (Instituto Brasileiro de Geografia e Estatística). A motivação, as hipóteses (Brest, Cananeia e IPCC) e os métodos utilizados são descritos, acompanhados por um breve histórico dos “Terrenos de Marinha”. Os resultados indicaram que os limites em (PP) estão bem dentro da área da praia. Eles foram determinados de acordo com a Lei No. 9760 e há a necessidade de reativar a rede nacional de medidores do nível do mar.

Palavras-chave: nível relativo do mar, Lei Brasileira, Terrenos de Marinha, praia do Pulso, nivelamento geodésico, área costeira sudeste, aquecimento global, aumento do nível do mar.

\section{REFERENCES}

Belfort Vieira JD. 1928. Publicado em 1942. As Marés, Observação, Estudo e Previsão no Brasil. Observatório Nacional (ON), Rio de Janeiro, RJ, 169 p.

BlitzKow D. 1998. Monitoramento das Condições Geodinâmicas dos Marégrafos de Cananeia e Ubatuba: Brasil, Lat $\left(24^{\circ} \mathrm{S}\right)$. Afro-América GLOSS News, 3. www.mares.io.usp.br/aagn/ - ISSN 1983-0319. 
CHAO BF. 1999. Concrete testimony to Milankovitch Cycle in Earth's Changing Obliquity EOS Transactions. Am Geophys Union 77(44): 433.

Douglas BC. 1991. Global Sea Level Rise. J Geophys Res 96(4): 6981-6992.

Douglas BC, Kearney MS and Leatherman SP. 1991. Academic Press. International Geophysical Series 75: 65-95.

FrançA CA DE S. 2000. Contribuição ao Estudo da Variabilidade do Nível do Mar na Região Tropical Atlântica por Altimetria por Satélite TOPEX/POSEIDON e Modelagem Numérica. Tese de Doutorado, Instituto Oceanográfico da Universidade de São Paulo, SP, Brasil, 274 p.

FRANCO AS. 2000. Utilização do nível médio do Mar para fins Ambientais e Geodésicos. Afro-America GLOSS News 4. www.mares.io.usp.br, Icon AAGN. ISSN 19830319.

Franco AS And Mesquita AR De. 1986. On Practical Uses of Filtered Daily Sea Level. IHR 6(2): 133-141.

Lemos A. 1928. Marés e Problemas Correlativos. Observatório Nacional, Rio de Janeiro, RJ, 92 p.

Mesquita AR DE. 1994. Variação do nível do Mar de Longo Termo. Inst Est avanç Documentos, Série Ciências Ambientais, 20: 47-67.

MesquitA AR DE. 1998. O Programa IOUSP para o "Global Change": Origem e Contribuições Inst Est avanç Universidade de São Paulo, São Paulo, SP, Brasil, Vol. (único), p. $130-149$.

Mesquita AR DE. 2003. Sea Level Variations along the Brazilian Coast: A Short Review. In: KLEIN AHF ET AL. (Eds), Proceedings of the Brazilian Symposium on Sandy Beaches. SI JCR 35: 21-31.

Mesquita AR de, Blitzkow D, França CA de S, TraBANCO JLA, CORRÊA MA AND MONTEIRO MQ. (in press). Nível Relativo do Mar de 1831 em Barra do Una. No prelo, Brazilian Journal of Geophysics (RBGf). http://www.mares.io.usp.br/aagn/51/una/una.htm - ISSN 1983-0319.
Mesquita AR De And Harari J. 1983. Tides and Tide Gauges of Cananeia and Ubatuba - Brazil (Lat 24 $50^{\prime}$ ) Relat Int Inst Oceanogr, Universidade de São Paulo, São Paulo, SP, Brasil 11: 1-12.

Mesquita AR de, Harari J And França CA DE S. 1996. Global Change in South Atlantic: Decadal and Intradecadal Scales. An Acad Bras Cienc 68(Suppl 1): $117-128$

MiNiUSSI IC. 1963. Hidrografia. In: Levantamento Oceanográfico Meteorológico da Enseada do Mar Virado. Ubatuba. Estado de São Paulo Contribuições Avulsas, Inst Oceanográfico, USP, São Paulo, SP, Brasil 5: 9-23.

Peltier WR. 2001. Global Glacial Isostatic Adjustment and Modern Instrumental Records of Relative Sea Level History. In: Douglas BC, Kearney MS and LeatherMAN SP, Sea Level Rise History and Consequences, 1991. Academic Press. International Geophysical Series 75: 65-95.

Occhipinti AG. 1963. Potencial de Poluição Atmosférica. In: Levantamento Oceanográfico MeteorolóGICO DA ENSEADA DO MAR VIRADO. Ubatuba. Estado de São Paulo. SP. Contribuições Avulsas. Inst. Oceanogr. USP, São Paulo, SP, Brasil 5: 71-118.

PSMSL - Permanent Service for the Mean Sea LEVEL. 1999. England - of IAPSO (International Association for the Physical Sciences of the Oceans). POL (Proudman Oceanographic Laboratory), Liverpool University, Liverpool, UK.

http://www.pol.ac.uk/psmsl/programmes/gloss/info.html.

SPU - SERVIÇO DO PATRIMÔNIO DA UNIÃo. 1999. Cronologia Básica da Legislação Patrimonial. Ministério da Fazenda da República do Brasil. Basic Chronology of Equity Legislation, 1 p.

TÁBUAS. 1989. Tábua de Marés para o ano de 1989. Costa do Brasil e Portos Estrangeiros. Diretoria de Hidrografia e Navegação, Rua Barão de Jaceguay, s/n, Niterói, RJ, Brasil. 